IRA-International Journal of Management \& Social Sciences

ISSN 2455-2267; Vol.05, Issue 03 (2016)

Pg. no. 467-478

Institute of Research Advances

http://research-advances.org/index.php/RAJMSS

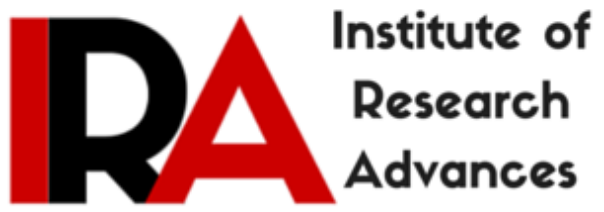

\title{
Nepal's Quest for Development: A Mis-driven Cosmetic
}

\author{
Atindra Dahal \\ (PhD, Issues of Nation Building, M. Phil./ M.A.: English Language and Literature and M.A. Political Science) \\ Associate Professor, Kathmandu School of Law, Bhaktapur Nepal.
}

Type of Review: Peer Reviewed.

DOI: http://dx.doi.org/10.21013/jmss.v5.n3.p10

\section{How to cite this paper:}

Dahal, A. (2016). Nepal's Quest for Development: A Mis-driven Cosmetic. IRAInternational Journal of Management \& Social Sciences (ISSN 2455-2267), 5(3), 467478. doi:http://dx.doi.org/10.21013/jmss.v5.n3.p10

(C) Institute of Research Advances

\section{(c) EY-NO}

This work is licensed under a Creative Commons Attribution-Non Commercial 4.0 International License subject to proper citation to the publication source of the work.

Disclaimer: The scholarly papers as reviewed and published by the Institute of Research Advances (IRA) are the views and opinions of their respective authors and are not the views or opinions of the IRA. The IRA disclaims of any harm or loss caused due to the published content to any party. 


\section{ABSTRACT}

Though people in Nepal long term have been desperately waiting the life changing development, still to be reeling with pain has been a culture of compulsion there. There are basic two misadventures that have hampered the functional development of nation then caused an invincible failure; those are: a) failure to understand that the development means economic in culture and nature, and b) failure to internalize that the strength of political leaders matters more than the style or name of reign being practiced. This paper has in-detail elaborated and explored the very issues and justifies how the development is misconceived then mis-constructed in Nepal.

Keywords: Development, Politics, Economy, Change, Purity

Development has been one of long awaited fruits of democracy in Nepal. Though other sorts of social changes and relative progress seem to be somehow active, economic transformation and significant financial progress, what people are desperately expecting, are still not accomplished and even seems unlikely, anon. All political changes were supposed to have earned rapid and radical economic progress with speedy acceleration. There were various political changes and experimentations in last 70 years of democratic exercise and every sort of mutations had only the economic development as the first and foremost prioritized agenda. But the real and very one development and progress of nation seems largely sidelined and overtaken. There are basic two misadventures that have hampered the functional development of nation then caused an invincible failure; those are: a) failure to understand that the development means economic in culture and nature, and b) failure to internalize that the strength of political leaders matters more than the style or name of reign being practiced.

\section{Sidelined 'Economic Development'}

Despite the frequent political changes, Nepal is not yet able to harness economic prosperities and galloping growth as committed by the initiator of political changes. The long time, the economic development of Nepal is slackening and sluggish in to same growth rate. Largely, the economic progress seems either constant or even backfiring as well; it is snail sailing rather. The real and root reason that still makes twists and turns for people's expectation and builds massive mass pessimism on politics is that there has not been significant economic development since long. The given graph from report titled Nepal's Economic Outlook too notes acute absence of any significant growth in PCI of Nepal for many of last years.

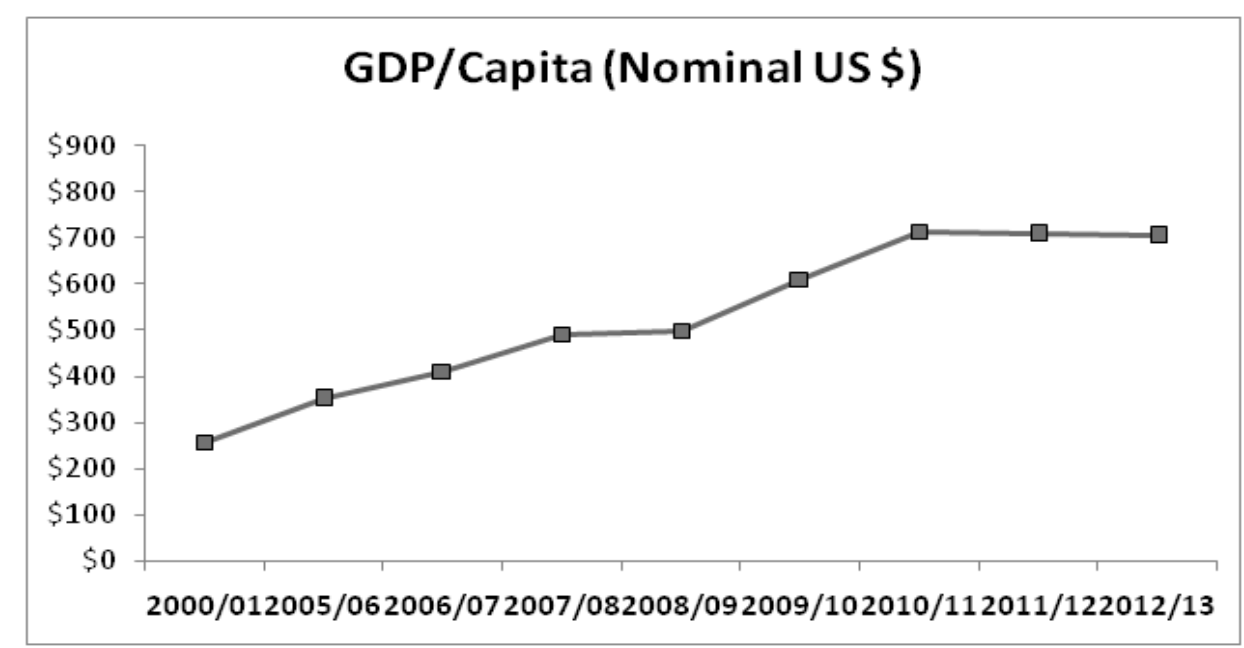


Basnet and et al write "Nepal has not achieved meaningful structural economic transformation[...]since 1995 it has been growing at an average of 2.5 percent with negative or zero growth four times in this period" (14) then assimilate the fact that the economic progress, which is factual index of development for people and nation, in Nepal is below standard.

And noting "unfavorable business conditions are responsible for the lackluster performance, in some years" (9) the above mentioned report, through below mentioned graph, depicts a dark and desolate figure of economic growth rate in almost every sector as it is either standstill or in declining mode for couple of years.

Economic growth Rate (\%) by sectors (at constant 2000/01 price)

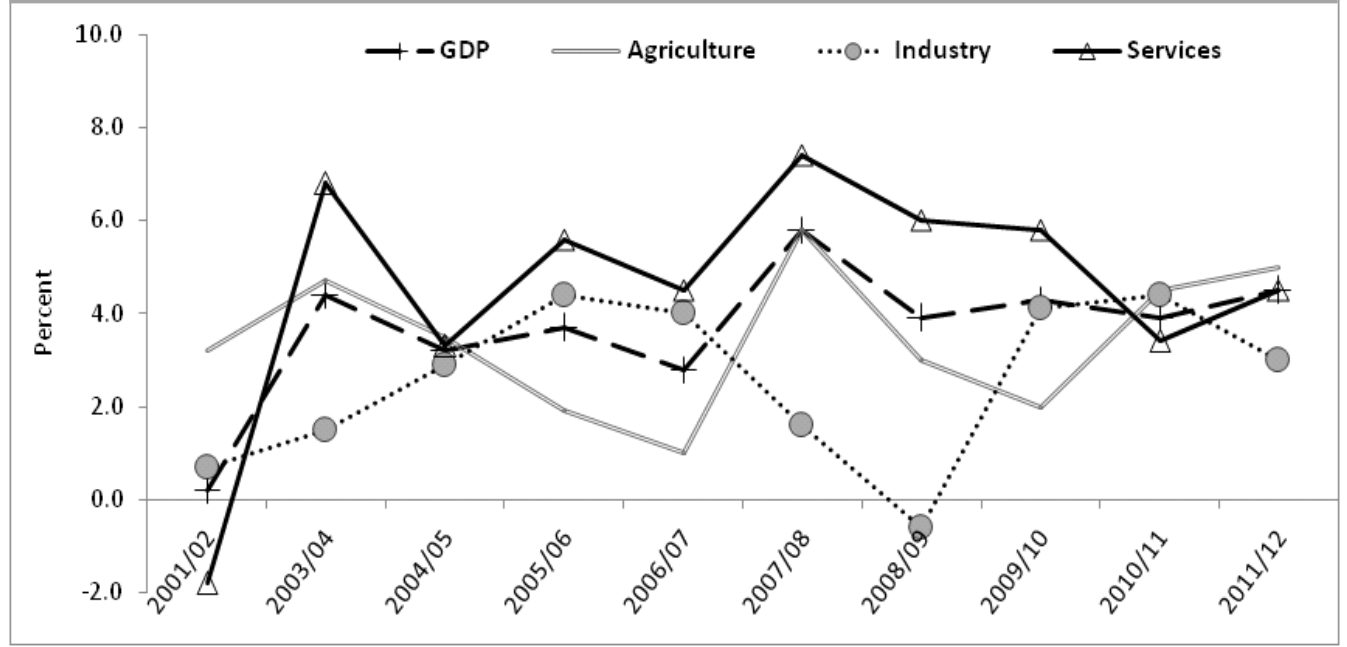

Thus, for the long time, the level of poverty is same and severe in Nepal. Self generated economic mobility and strength is almost absent. Even a slow progress in economic development is based on remittance. And remit based economic development is an elusive and perishing joy because it offers an immediate solace to unemployment, reduces poverty but tags and poses deadly problems ahead.

The real development lies behind economic development and people feel changes if and only if economic prosperity seems possible to them. Bellù notes it as "actual socio-economic systems" (5) and argues that "economic development has traditionally been seen as the first form of development indicated by PCI" (6). Adelman and Morris use the word 'expected development' to rate the very course. Aghion and Armendáriz feel it to be a 'most needed approach' to mass people. Bourguignon \& Morrisson deem 'economic inequality' as crux of the problem then urge to overcome such inequality to assure right path of development. But Nepal has missed it for long and remained almost stand still or back slackening on these issues thus has missed the real development.

Making Nepal feel shame, countries in her vicinity have made remarkable changes. Nations like Thailand, Korea, Taiwan, Vietnam, Hong Kong, Malaysia and Singapore have progressed a lot. They are called tiger economy as well. In 40 years of establishment, Singapore has 82000 \$ PCI. Yusuf calls it as miracle in East Asia which has led many of countries in this circuit from 'kitten to tiger economies'. Many internal factors, besides dominantly the export-orientated business module have contributed to such growth. A spectrum of these factors is very broad: from 'purely' economic (macroeconomic stability, effective industrial policy, etc.) and institutional (good governance, adequate management, mass education) to such social-cultural factors, as traditions of communalism, social paternalism, or heritage of Confucianism, Buddhism and Taoism. 
Sachs in 2003 had forecasted that China's economy would outweigh that of the UK and Germany within five years, pass Japan's around 2015, and overtake the United States by 2040. It was professed that within less than fifty years, East Asia could dominate the world economy; if the countries currently distance from the current wealth of Japan - including China and Korea - continue to track a similar growth trajectory to that of Japan some years ago. The East Asian economy was guessed to account for half of global GDP by 2050. But the growth of those countries is even faster than the expectation/forecasting. China has already been the first economy of the globe. Thus, the economic empowering of those nations seems very rapid and vibrant but Nepal has ever missed it despite having boundless and beautiful business options.

Maddison highlights 'galloping PCI' in many Asian countries including Korea and argues that the economic proliferation those countries have enabled them command real progress and prosperity. Holliday and Wielding write 'we call Asia's tiger economies: Hong Kong, Singapore, South Korea and Taiwan" (11) and O'Connor writes that tigers were starting to be able to afford welfare state development then accepts that the sound financial growth and economic strength exist in those Asian Buddhist nations. Tilak highly eulogizes their speedy economic development then mentions that these tiger governments gave education a very important role in social and economic development. Thus the notion that developments mean largely economic in nature is once more justified.

Despite garnering any lesion and insights from such vibrantly progressing neighbors, Nepal is still in the same position for last 20 years. Nepal has wasted the time in name of armed insurgencies and transitional politics. Bhetwal notes no extensive economic liberalization in this period thus Nepal faced a complete failure on financial development and Paudel calls it no real growth. Koirala vents reservation on the lack of 'promoting employment intensive growth'. A set of separate papers by Khan, Shrestha Chndra and Shrestha, Rajendra too rightly note the economic growth of Nepal is often sluggish and poor then argue that the real facade of development is being missed on same ground.

Nepal's political parties have never had the agenda of economic development as first. Chaudary, as an industrialist and the first dollar billionaire always has made a serious objection on this and has noted it as myopic nature of politicians. Saying "mere feelings can't drive the nation, to make it sound, economic aspects should be firm" (trans: 20) he enjoins the people to be productive and remain economically fertile. And Government is expected to prioritize the very agenda in politics. Nonetheless, parties never had any solid strategic planning for economic development of the country whereas only changes for reign and its systems were highlighted. Subedi rates it as political failure in two folds: one to assure stability and other to prioritize the issues of economic development.

Dearaniyagala believes that the civil conflict of Nepal to have demolished and deviated the issues of economic development. Whereas, Pathak and Horning blame Nepali Congress for it and write, "The control of the bureaucracy by the National Congress could be a powerful tool to block implementation of economic reforms and weaken the CPN-M" (8). Hachhethu believes the 40 points demands raised by Maoist at the advent of armed conflict to have taken the issue of economic progress though not principally considered as major principle later on once they formed the government. Hatlebakk urges the economic activities in Terai have gone illusive and less forced once Madesh upheaval demanding better political representation had an onset on 2007. Having assumed, 'though ever and always being 'tool of catalyst' for conflict despite political participation the economic development among marginalized populations were disappointed in every changes' Lawoti feels that Nepal's economic development is laid at back. Mahat argues that The CPN-M grew out of these disillusions and appealed specifically to socioeconomic grievances as it mobilized in rural areas (337) nonetheless it has not given any tangible fruits. Whelpton notes even that Maoist movement was remarkable to assure 'intensified political changes' but not so in terms of economic agendas. Thus Nepal's quest of development always remained far left and in a remote distance. Unless economic development is on hold, other sorts of empowerment will be mere a 
pool of an ideal pipe-nine; the strength and power is economy than rest of any abstract feelings. Policy conceptualizes it but practice makes people feel; thus economic development is first and foremost need but Nepal always missed it a lot.

Not having policy of automated financial development is another misfortune of Nepal. Though Nepal has economically sustained and crippled slowly, for couple of last years, it is based on remittance from thousands of youths working in other nations. Maimbo and Ratha find so many Regional development banks, bilateral aid agencies and other international agencies also adopting ambitious programs to collect information and facilitate remittance flows. Seddon too notes Nepal's growing dependence on remittance and claims that almost $30 \%$ of remittance is still coming from unofficial channel which is even not noticed. Even going to foreign employment is not easy as Bhattarai has talked in detail about 'host of hurdles in to home country and destination'. Garner and friend note it as that going foreign land is a major function to Nepali people and show a data that the number has already crossed 1 million in 2007 just 15 years of its formal inception. That is too only the data of formal channel. Pant highlights the share of remittances in the current account receipts soared from 27.4 percent in 2000/01 to 33.6 percent in 2005/06. Latest data infallibly show that Nepal has growing dependencies. Thus the real economic picture of nation is quite bleak and seems disgraceful.

The remittance comes to be almost $60 \%$ of the budget and GDP and recent news has calculated that Nepal is the third largest country being dominantly contributed by remittance in GDP. Though Nepal has earned money through remittance, the real economic strength of nation is backfiring or stagnating because her dependency on others is increasing largely. Rather import of Nepal has increased many times and export is inexplicably disproportionate; and following it, the trade deficit of Nepal is widened a lot. A report from statistic analysis section department of custom, infallibly highlights the widening import gap in following figures. But, Nepal's consumption pattern has changed; people are exposed to modern technologies and other sorts of luxury livings in compared to past. Since there are no any factories to cater those types of goods and services, the dependencies are widening.

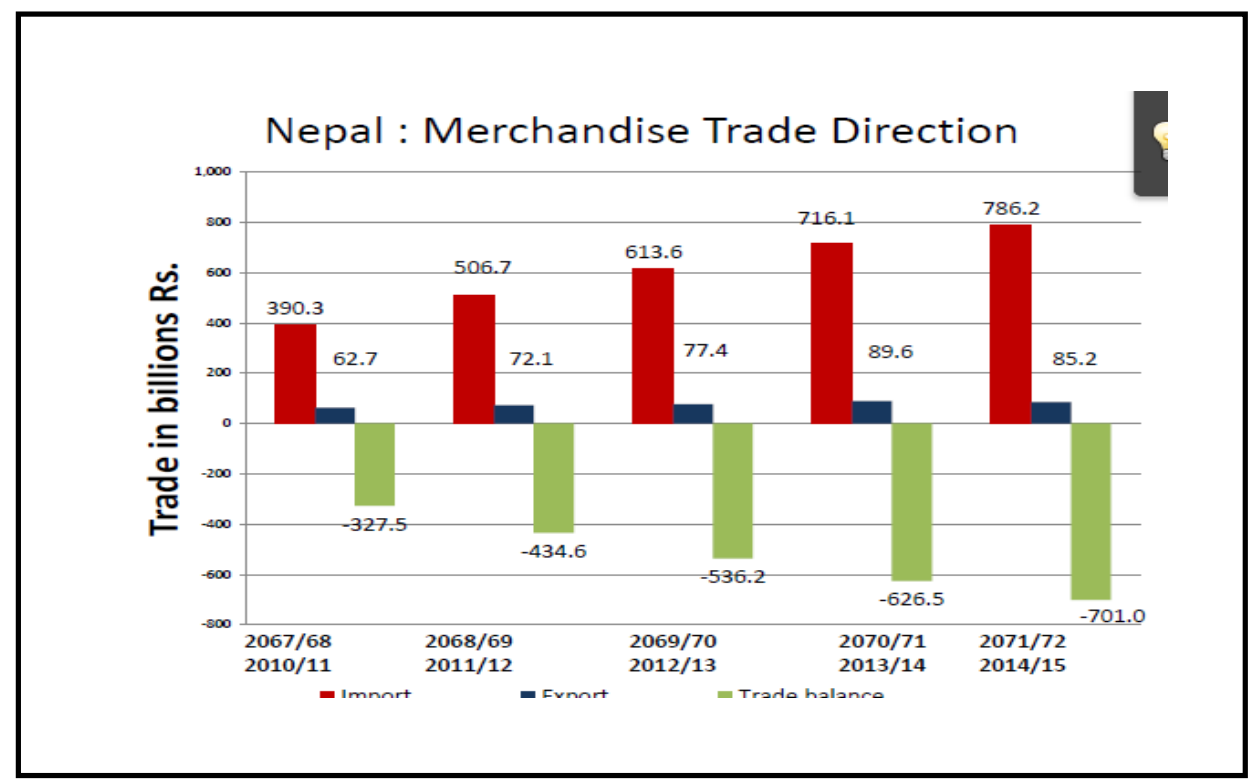


Other countries of nearby areas are making much profit bearing business deals and projects. Mere a single Samsung company of South Korea bears $45 \%$ of GDP. Countries are coming with much fertile and alluvial area-exploration of business. But Nepal neither has any such result bearing business prospect projecting activities nor seems to have any anon.

Mere provisioning rights in lines of laws won't bring real and expected changes. In fact the employment opportunities, which are key marker of positive progress, are not extensively enlarged. Still, many people suffer acute shortage of employment. A report titled Nepal labbour market update reads "in response to the lack of job opportunities, Nepalis continue to seek employment outside the country, mostly in India, the Gulf Cooperation Council (GCC) countries and more recently, in Malaysia" (3). This makes an incontrovertible hint that Nepal really lacks positive economic growth and progress.

Though being completely insouciant and indifferent, Nepal has high business possibilities. Middle East countries are all relying on the strength of selling oil and their economic standard is very high. Even PCI of those countries goes above 50000 US dollar. But the oil stock is about to expire soon. Nepal too, if planed seriously, can control world's energy market by supplying hydro energy once oil stock passes or even earlier as hydro is the cheapest energy. KG hydro plant in Japan and Pharping plant in Nepal were initiated in the same year; Thai air and RNAC were established into the same day. But those initiatives didn't fruit better to Nepal as she failed to have enough strong steps. Many of such reliable progress indicative projects have reeled under severe failure. Buddhism tourism may be the next and other projects of high possibilities are there which in very short period might significantly change the economic status of Nepal from gloomy present to gladdening futures.

The real development is financial. The discriminations made from one race to another and from one community to next are issues only shifted into footnotes of history books. Still there exists the discrimination based on financial sufficiency of individual; thus class is over the caste. If economic strength is good, all rights will be automatically commanded. No any individual of scheduled caste, any gender or race is discriminated if his/her economic condition is sound. Authors ideating nation building too largely argue in the very line. Zolberg's assertion "indeed, one scholar should note all the time that nation-building takes precedence over all other tasks including economic development" (461) makes same thought. Smith and colleagues with the idea "European nation-state building is based on making the nation and state spatially congruent and that linguistic and educational standardization is therefore commensurate with the running of a more efficient national economy and 'scientific' state bureaucracy, and with creating a more harmonious and loyal citizen-polity" (103) too express views in line of Zolberg, who regards economic development to be main and most rated index of development. Mazrui as well assimilates the fact that only the economic prosperities of people holds ground to suffice for other developments in nation. Phukon focuses on making a sharp wit on creating economically equitable and equal opportunities for all people.

The series of arguments infallibly justify that economic prosperity is the first and foremost desirable feature of real development. But the very concern is always sidelined in Nepal. As economic prosperity is not taken with interest, Nepal often remained behind and in distance in course of assuring real change and meaningful development to the people.

\section{Infatuation on Policy over Polity}

Hoping that economic prosperity will be based to some sorts of political policies, Nepalese people have inordinately and excessively rated policies then have relentlessly immersed into changing them. Often the blames were made to existing political pattern then tantalized that altering the system would abound the economic gains ahead. From Rana Regime to Republic, there are frequent political changes and each of those actions was in anticipation of economic systematization and prosperity of the nation. These sorts of 
changes are very rare in world. US had independence war 1778 and black civil right movements 1963. France had glorious revolution in 1785. India had same in 1947, China in 1949 and Russia in 1917 respectively and very same have been functioning as par the expectation of people till now. But the context of Nepal is somehow in other-way.

Upadhya writes "Till present time, political change in Nepal was held within a time frame depicting the capricious nature of Nepali politics, which lacks the leadership vision for Nepal's future. Nepali mass movements and political parties brought the program with short term solution and gain the power. For sustainable solution, economic programs were not implemented" (83) and depicts the major and solemn problem of Nepal as quest of development is largely mis-driven since leadership was not visionary to have progressive and positivist economic gains.

Dahal argues that even in modern democratic age, poor people in Nepal are not the real beneficiaries in development projects but the elites living on the top have always remained the true beneficiaries of all development models and Whelpton compares this ethogeniss with the British raj in India. The assertion is that even political changes are not capable to command the economic progress as expected to normal people.

Nepal has changed almost a government every year in average. Such terrible instability has made ground for breeding corruption, fluctuating polices and so on. Baral, noting it as the severe bronchitis of politics in Nepal, regards as major reason for nation's deterioration. Political inclusivity and making a large number of representative or modeling new constitutions are regarded as changes. Hachhethu argues that the democratic apparatus between the years 1990-2002 had been overwhelmed by power-centric intraparty and inter-party conflicts and Baral notes mis-governance to be chief marker of Nepali politics. Leaders always thought only constitution to be a divine solace and pill to evacuate the nation. But many countries do have constitution which is written many years back. Though Nepal has kept on blaming this or that systems of reign to be blameworthy for deterioration of nation, many countries have progressed in monarchy, republican and rest of others systems as well. Thus preference to any specific political system has nothing to do but Nepal often got trapped into same illogical explanation.

America has republican government and still takes good progress. Asian tigers, which are of recent emerging, have significant economic progress though some of them have monarch, some have parliamentarian executive and some have religious robustness. Nepal never grew to have better polity and characteristics, which was a dire need. Mere preferring on policy doesn't work better, for example though Nigeria and many of African nations do have the republicanism, which we are infatuated with, those have spins of bad lucks as well.

De Tocqueville argues that difference in the opportunity to realize personal pecuniary gain afforded by autocracy and democracy directly to the number of people matters. In case having gain and benefits equal, people have trust on the system of any types irrespective of the name given to it. Diermeier and et all raise an issue of Weibull hazard analysis in politics and supports to De Tocqueville's argument that public fascination or reservation is not on words rather works cabinet does to them.

Fing and Paul write "The resolution of this puzzle is that democratic transitions occur both in economies that are economically successful as well as those that are economically unsuccessful so that no unambiguous cross-sectional correlation between democracy and growth should be evident" (4). And subsequent studies justify that instability and uncertainty are on ground of inability and inertia of leaders not of the system. Lake and Baum too regard financial crisis as political crisis then argue that various contradictory and controversial political systems of world sphere be successful on ground of their strength to command financial success. McGillivray notes only two options: either improving economic policies or facing defeats. Many sorts of experimentations have been meeting a tragic end though they are named 
same to system which is quite successful somewhere else. Przeworski regards the affluent society mandatory for democracy to have a better survival. Thus mere a unique name or alteration of system of regime is not sufficient condition. Roemer thus argues for reinforcement of theoretical deduction and practical induction as well.

Mere political positioning and power mongering has been the centre of attraction for all the power actors in Nepal. Neither any sound developmental plans are enacted nor thought so. Had they had intentions and planning, they could have done irrespective of any difficulties.

Koslowski and Kratochwil write 'nationalist politics was victorious, do functionalist argument' (226) and rate the values of functions politicians perform than words they use. Bardach calls 'problem definition' and Mintrom notes 'people's skill' for the same idea to reinforce the notion that mere defining the system won't solve the problem rather skills value for it. Bell and Hindmoor saying 'multifaceted systems of governance' make same line thought that people care outputs than mere commitments. They highlight that better governance is possible in country irrespective of fact that what so ever name is given. Boyne writing 'success resides in meeting targets and achieving outcomes' argues that mere regime won't mean anything unless it succeeds to work on favor of people.

Dye claims "even if programs and policies are well organized, efficiently operated, adequately financed, and generally supported by major interest groups, we may still want to ask, So what? Do they work? Do these programs have any beneficial effects on society? Are the effects immediate or long range?" (332) and justifies that progress of nation depends on strength and purity of political practitioners than policy they carry. Unfortunately, governments have done very little to answer these more basic Questions. Gastil with using a phrase 'collective choices in the public interest' means to exhibit the truth that rather than name of regime the strength it unleashes is more important and the first choice of people.

But the greater and ever undefeated and unbeatable challenge of Nepal's democracy is that despite continuations of ongoing few of survival functions, no government came with some sound policies to generate and kindle complete economic changes. People are not soliciting the words rather are more interested to look for works, for what most of the systems derivers faced a great fiasco.

Acharya writes "continuous dominance of the few political leaders in both political parties and government, with no significant changes to political performance and delivery despite the increase in political mobilization at the grassroots level and regular parliamentary/local elections" (127) then admits that the politics is not being meaningful for public. Adams notes it as 'existing culture' and Carothers calls it 'feckless pluralism'. Hall's idea of incomplete peace process and unending debate over regime model too lays stress for the unsolicited infatuations paid over the political system of nation.

Lawoti takes the concept of reinforcement of frustrating political practice, i.e., intensification of inter and intra-party wrangling, buying off lawmakers in order to make or break a government, and the widespread use of "money and muscle" in elections 'exclusionary democratization'(365) to highlight the major involvement in ongoing political regimes which is away from concentration in development of the people. Riaz and friends note the same and Suri calls it steady leadership whereas Whelpton urges reexamining the political potentials for the same misfortune and mis-driven interpretation which has tantalized people here so forth. Lawoti and friend as well argue that increasing public distrust toward the democratic system and political leaders is based not on the name but it is so rather on strength of them to cause lifetime practical changes. 
People in Nepal looked the development into a particular form of government and style of reign. But rather than style the strength built would drive it so. Very notion is neither accepted nor respected. Hutt writes that the socio-economic situation of Nepal was quite unjust and unfair and perceives very argument that the expectation of development with name or systems or words given to it was quite unfair because development is neither fair nor possible because of only the name. The backwardness of Nepal is not because of policy or reign rather it is inertia and ineffectiveness of people who handled the systems.

\section{Conclusion}

Thus, Nepal's development has remained largely a pipe-nine, rather. As economic prosperity has been always sidelined and the infatuation over tag of political system than strength and potentials it holds was major engagement, the failure has been an unending recurring brand episode in nation. Countries exploring the strength of leaders' irrespective of forwarding either attraction or hatred on name of systems and overriding mere political function with economic priories are now grown up as emerging nation. Being small in territory or less in population is not misfortune to them and neither is so for Nepal. But having challenged and churched economy is the cause. Unless, Nepal takes bold steps to overcome it, the mission development seems not to be possible. Because development is economic in nature and outcome of strength of political leadership rather than systems applied. Failure to acknowledge it and adopt practices accordingly has made Nepal's quest for development mere a mis-driven cosmetics and a mirage. Unless taking a bold revision and breakthrough and making an onset to view alternatively as highlighted, it seems no easy in near future too.

\section{References}

\section{Books and Articles}

1. Acharya, Ina. "Working Under Monarchy: Political Leadership and Democracy in Nepal." Asian Politics \& Policy 1-1. January-March 2009, P+127-141.

2. Adams, Brad. "Nepal at the Precipice." Foreign Affairs 84-5. September- October 2005, P+ 121134.

3. Adelman, I and Morris, C.T. Society, Politics and Economic Development. A Quantitative Approach. USA: Hopkins Press, 1967.

4. Aghion P. and Armendáriz B. A New Growth Approach to Poverty Alleviation. MIMEO: Harvard University, 2004.

5. Baral, Lok Raj (ed.) Nepal: Parties and Parliament. Delhi: Adroit, 2004.

6. Baral, Lok Raj (ed.) Nepal: Facets of Maoist Insurgency. Delhi: Adroit, 2006.

7. Bardach E. A Practical Guide for Policy Analysis: The Eightfold Path to More Effective Problem Solving. Washington, DC: CQ Press, 2009.

8. Basnett, Yurendra, Giles Henley, John Howell, Harry Jones, Alberto Lemma and Posh Raj Pandey. Structural Economic Transfermation in Nepal. A Diagnostic Study Submitted to DFID Nepal. London: Overseas Development Institute, 203 Blackfriars Road, SE1 8NJ, 2014.

9. Bell S. and Hindmoor A. Rethinking Governance: The Centrality of the State in Modern Society. Cambridge: Cambridge University Press, 2009.

10. Bellù, Lorenzo G. "Development and Development Paradigms". A (Reasoned) Review of Prevailing Visions. USA: Food and Agriculture Department of Untied States, May 2011. Issue Paper.

11. Bhattarai, Prakash. "Migration of Nepalese Youth for Foreign Employment: Problems and Prospects". A Review of Government Policies and Programs. Nepal: Oct, 2005.

12. Bhetuwal K.R. "Financial liberalization and Financial Development in Nepal." Economic Review, Occasional paper-19, April, Nepal Rastra Bank, 2007. 
13. Bourguignon, F. and Morrisson, C. Inequality and Development: the Role of Dualism. Journal of Development Economics 57:2, 1998. P+33-57.

14. Boyne G. A. "Explaining Public Service Improvement: Does Management Matter?" Public Policy and Administration, 19 (4). P+100-117, 2004.

15. Carothers, Thomas. "The End of the Transition Paradigm." Journal of Democracy 13-1. January 2002, P+ 5-21.

16. Chaudhary, Binod. An Encounter with Politics. Nepal. CG Foundation. 2069.

17. Dahal, D. R. Nepal's Democratic System has Failed... ! The Telegraph Weekly, 5, 2000.

18. De Tocqueville, Alexis. Democracy in America. Trans. and edited by Harvey C. Mansfield and Delba Winthrop. Chicago: University of Chicago Press, 2000.

19. Dearaniyagala, Sonali. "The Political Economy of Civil Conflict in Nepal." Oxford Development Studies. Vol. 33, No. 1, P+ 47-62, 2005.

20. Diermeier, Daniel and Merlo, Antonio. "Government Turnover in Parliamentary Democracies." Journal of Economic Theory. 94(Sept.) P+ 46-79, . 2000.

21. Dye T. R. Understanding Public Policy. New Jersey: Pearson Prentice Hall, 2005.

22. Feng, Yi and Zak, Paul J. "A Theory of Democracy." Claremont Graduate University Working Paper, 2001.

23. Feng, Yi. "Political Freedom, Political Instability, and Policy uncertainty: A study of Political Institutions and Private Investment in Developing Countries," International Studies Quarterly 45:271-294, 2001.

24. Gastil J. Political Communication and Deliberation. Thousand Oaks, CA: Sage, 2008.

25. Graner, E. and Seddon, David. "Nepal's Remittance Economy: A Decade Change". Nepalese Economy: Towards Building A Strong Economic Nation-State. Edited by M. K. Dahal. Kathmandu: Tribhuvan University, 2004.

26. Hachhethu, Krishna. "The Nepali State and the Maoist Insurgency, 1996-2001" Himalayan People's War: Nepal's Maoist Rebellion. Edited by Michael Hutt. Bloomington Indiana University Press, 2004. P+ 58-78.

27. Hachhethu, Krishna. "Nepal: Towards A Democratic Republic". Economic and Political Weekly. Vol. 42 No. 20, May 19 - May 25, 2007.

28. Hall, Andrew. "Nepal: An Incomplete Peace." Asian Affairs 42-3. October 2011, P+ 403-418.

29. Hatlebakk, Magnus. Economic and Social Structures that May Explain the Recent Conflict in the Terai of Nepal. Bergen: Chr. Michelsen Institute, 2007.

30. Holliday, Ian and Wilding, Paul. Welfare Capitalism: in East Asia Social Policy in the Tiger Economies. USA: University of Manchester/ Palgrave Macmillan, 2003.

31. Hutt, Michael. Himalayan People's War: Nepal's Maoist Rebellion. Bloomington: Indiana University Press, 2004.

32. Khan, A.R. "Globalization and Sustainable Human Development: An Assessment of Challenges Facing Nepal". UNCTAD/UNDP Occasional Paper, 2010.

33. Koirala, Govind P. "Promoting Employment-Intensive Growth in Nepal: Policy Analysis of Agriculture Sector with Potential for Growth and Employment". Background Paper, ILO, Geneva and Kathmandu, 2011.

34. Koslowski, Rey and Kratochwil, Friedrich V. "Understanding Change in International Politics: The Soviet Empire's Demise and the International System" Reviewed work(s): International Organization, Vol. 48, No. 2 (Spring, 1994), P+. 215-247. Published by: The MIT PressStable URL: http://www.jstor.org/stable/2706931.

35. Lake, David A. and Baum, Matthew A. "The Invisible Hand of Democracy: Political Control and the Provision of Public Service." Comparative Political Studies 34(6):587-621, 2001.

36. Lawoti, Mahendra and Hangen, Susan. Nationalism and Ethnic Conflict in Nepal: Identities and Mobilization after 1990. Oxon: Routledge, 2013. 
37. Lawoti, Mahendra. "Exclusionary Democratization in Nepal 1990-2002." Democratization 15-2. March 2008, P+ 363-385.

38. Lawoti, Mahendra. Looking Back, Looking Forward: Centralization, Multiple Conflicts, and Democratic State Building in Nepal. Washington D.C.: East-West Centre, 2007.

39. Maddison, Angus. The World Economy Historical Statistics. Paris: OECD Development Center Studies, 2003.

40. Mahat, Ram Sharan. In Defence of Democracy: Dynamics and Fault Lines of Nepal's Political Economy. New Delhi: Adroit Publishers, 2005.

41. Maimbo, Samuel Munzele and Ratha, Dilip. Remittances: Development Impact and Future Prospects. Washington, D.C.: The World Bank, 2005.

42. Mazrui, Ali. "Traditional Coverage and Efforts of Integration in East Africa". Edited by S. N. Eisenstad and Stein Rokkan. Building States and Nation: Analysis by Regions. Vol II, California. Sage Publication, 1973

43. McGillivray, Fiona. Targeting the Marginals. Princeton: Princeton University Press, 2003.

44. Mintrom M. Peoples' Skills for Policy Analysts. Washington, DC: Georgetown University Press, 2003.

45. O'Connor, J. The Fiscal Crisis of the State. New York: St Martin's Press, 1973.

46. Pant, Bhubanesh. " Remittance Inflows to Nepal: Economic Impact and Policy Options." Economic Review 18: 20-26, 2006.

47. Pathak, Bishnu, and Horning, Neil. Nepal's Paradigm Shift: Industrial Capitalism in the Name of Socialism. Kathmandu: Conflict Study Centre, 2008.

48. Paudel, N. P. "Financial System and Economic Development." Nepal Rastra Bank in 50 Years. Nepal: Sajha Prakashan, Pulchok, Kathmandu, Nepal, P+ 176-201, 2005.

49. Phukon, Girin. "Politics of Identity and Nation Building in Northeast India: A Case of Assam". Politics of Identity and Nation Building in Northeast India. Edited by Girin Phukin \& N. L. Dutta. India: South Asians Publishers, 1997. P+ 123-133.

50. Przeworski, Adam. "Why Democracy Survives in Affluent Societies?" Paper presented in the New York University Department of Politics Political Economy Seminar, 2001.

51. R. Islam: Nepal: Addressing the Employment Challenge through the Sectoral Pattern of Growth. Kathmandu: ILO, 2014.

52. Riaz, Ali and Subho Basu. "The State-Society Relationship and Political Conflict in Nepal (17682005)." Journal of Asian and African Studies 42-2. April 2007, P+123-142.

53. Roemer, John E. Political Competition: Theory and Applications. Cambridge: Harvard University Press, 2001.

54. Sachs, Goldman. "Dreaming with BRICS", Global Economics Paper No 99, October 2003.

55. Seddon, David. "Nepal's Dependence in Exporting Labor." Available in: http://www.migrationinformation.org/Profiles/display, 2005.

56. Shrestha, Chandra B. "Investment and Employment in Nepal's Infrastructure Sector: A Policy Oriented Study". Background Paper, ILO, Geneva and Kathmandu, 2011.

57. Shrestha, Rajendra Prasad "Growth of Output and Employment in Manufacturing Industries in Nepal: Achievement, Prospects and Policies". Background Paper, ILO, Geneva and Kathmandu, 2011.

58. Smith, Graham, Vivien Law, Andrew Wilson, Annette Bohr and Edward Allworth. Nationbuilding in the Post-Soviet Borderlands: The Politics of National Identities. USA: Cambridge University Press, 1998.

59. Subedi, B.K. An Introduction to Economic Development and Planning. Kathmandu: Vidyarthi Pustak Bhandar, 2006.

60. Suri, K. C. Political Parties in South Asia: The Challenge of Change. Stockholm: IDEA, 2007.

61. Tilak, J. Education and Development: Lessons from Asian Experience. New Delhi: National Institute of Educational Planning and Administration, 2000. 
62. Upadhyay, Prakash. "Reforms and Changes in Nepal: Political Sociological Perspectives on State Restructuring Process in the Post-Democratic Period." Crossing the Border: International Journal of Interdisciplinary Studies. Volume 3; Number 1; 15 January 2015. ISSN 2350-8752 (Print); ISSN 2350-8922 (Online)

63. Whelpton, John. A History of Nepal. Cambridge: Cambridge University Press, 2005.

64. Yusuf, Sh. "The East Asian Miracle at the Millennium." Rethinking the East Asian Miracle. Edited by J. E. Stiglitz and Sh. Yusuf. Oxford, N.Y.: Oxford University Press, World Bank, 2001.

65. Zolberg, A. R. "Patterns of National Integration". Journal of Modern African Studies. 5(4). 1967. $\mathrm{P}+449-467$.

\section{Reports}

1. Major Highlights of Nepal Foreign Trade Statistics 2071/72. Nepal: Statistics Analysis Section Department of Customs Nepal, 20 Aug. 2015

2. Nepal Labour Market Update. Nepal: ILO Country Office for Nepal, November 2014

3. Nepal's Economic Outlook 2013/2014. Nepal: Institute for Integrated Development Studies (IIDS) 2014. 